\title{
Prevalence of hepatitis A virus infection in Goiânia, Goiás, Brazil, by molecular and serological procedures, 1995-2002
}

\author{
Fabíola Souza Fiaccadori, Célia Maria de Almeida Soares*, Ana Maria Tavares Borges, \\ Divina das Dôres de Paula Cardoso/ ${ }^{+}$
}

\begin{abstract}
Laboratório de Virologia, Instituto de Patologia Tropical e Saúde Pública *Laboratório de Biologia Molecular, Instituto de Ciências Biológicas, Universidade Federal de Goiás, Rua 235, esquina com $1^{\mathrm{a}}$ avenida s $/ \mathrm{n}^{\mathrm{o}}$, Setor Universitário,
\end{abstract}

74605-050 Goiânia, GO, Brasil

\begin{abstract}
In this study, a total of 865 serum samples were collected between 1995 and 2002 from individuals living in Goiânia, Central Brazil, and clinically suspected of hepatitis. After exclusion of 162 samples which were positive for hepatitis $B$ virus or hepatitis $C$ virus, 703 samples were tested for anti-hepatitis A virus (anti-HAV) IgM antibodies by enzyme immunoassay. In addition, 588 of these samples and 22 fecal samples were analyzed by reverse transcription-nested PCR for HAV RNA detection, with positivity indices of $13.1 \%$ (77/588) and 54.5\% (12/22), respectively. A similar index of viral RNA detection in anti-HAV-IgM positive or negative samples was observed in serum samples. $H A V$ infection is a public health problem worldwide and this study underscores the extent of HAV circulation in our region.
\end{abstract}

Key words: hepatitis A virus - prevalence - anti-HAV-IgM - viral RNA - Goiânia - Brazil

Hepatitis A virus (HAV) infection is a public health problem worldwide. HAV belongs to the Picornaviridae family, Hepatovirus genus. The viral genome is a linear, positive sense, single-stranded RNA (ssRNA), of about $7.5 \mathrm{~Kb}$ in length (Buchen-Osmond 2003).

The endemicity of HAV infection varies between developing and developed countries. In Brazil, in recent decades, a change has been observed from high to medium endemicity for the infection (Tapia-Conyer et al. 1999, Tanaka 2000). The prevalence of hepatitis A varies greatly in different Brazilian regions, from 56\% in the South and Southeast to $93 \%$ in the North region (Carrilho et al. 2005) and in the Central region, Cardoso et al. (2000) observed a HAV infection rate of $32.6 \%$.

The HAV concentration in feces is high, extending from the incubation period until at least two weeks after the acute phase of infection (Tassapoulos et al. 1986, Koff 1998). In developing countries, HAV is transmitted mainly through the fecal-oral route, with the possibility of person-to-person transmission (Lemon 1985, Villar et al. 2002b). Viral RNA can be also detected in the peripheral blood, and in this way, parenteral transmission has been observed (Costa-Mattioli et al. 2002, Diwan et al. 2003, de Paula et al. 2004b, Gowland et al. 2004).

HAV viremia occurs even during the immunological window and thus, viral RNA detection is an important condition for the correct diagnostic of acute hepatitis cases of unknown etiology, as well as for patient monitoring. For this reason, viral RNA detection in serum, as well as in feces, has been performed through the reverse tran-

\footnotetext{
Financial support: $\mathrm{CNPq}$

${ }^{+}$Corresponding author: divina@ @etgo.com.br

Received 9 February 2006

Accepted 15 May 2006
}

scription polymerase chain reaction (RT-PCR), using primers designed for different genome regions (Seelig et al. 1992, Buti et al. 2001, Costa-Mattioli et al. 2002).

The present study presents data supported by molecular and serological procedures concerning the prevalence of HAV infection in Goiânia, Brazil.

\section{MATERIALS AND METHODS}

Samples - The samples in this study were collected from 1995 to 2002 from individuals in Goiânia. The 865 individuals enrolled in this study were referred by the Goiás state public health system to the Virology Laboratory/Federal University of Goiás, because they presented clinical signs of hepatitis such as jaundice, nausea, fever or abdominal pain. The serum samples were tested for viral hepatitis (HAV, HBV, HCV). Of these samples, 162 were positive for $\mathrm{HBV}$ or $\mathrm{HCV}$ and were excluded from this study. The 703 remaining serum samples were included, as were the 22 fecal samples collected from 22 of the patients.

The study was approved by the Research Ethics Committee of the Federal University of Goiás (COEP-UFG) 22000000289.

Serological tests - All serum samples were tested for anti-HAV-IgM antibodies with an enzyme immunoassay test, using a commercial kit (Organon-Teknika, Boxtel/ Netherlands) according to manufacturer's instructions.

Viral ssRNA extraction - For viral RNA detection we analyzed 588 serum samples that had sufficient material for this procedure and 22 fecal samples. The viral ssRNA was extracted according to the method described by Boom et al. (1990) with modifications. Briefly, buffer L6 (guanidine isothiocyanate/0.1M Tris- $\mathrm{HCl} \mathrm{pH} 6.4 / 0.2 \mathrm{M}$ EDTA pH8.0/Triton X-100), proteinase K $(10 \mathrm{mg} / \mathrm{ml}$ - Invitrogen/ Life Technologies, Carlsbad, CA, US), ethanol and silica (Sigma, St. Louis, MO, US) were added to $400 \mu 1$ of the sample. After the supernatant was discarded, the pellet 
was subjected to successive washings [buffer L2 (guanidine isothiocyanate/0.1M Tris- $\mathrm{HCl} \mathrm{pH} 6.4$ ), $70 \%$ ethanol and acetone]. Finally, the pellet was resuspended in DEPC -treated water.

RT-PCR and nested PCR - RT, amplification reactions, and primers followed the protocol described by de Paula et al. (2002) with modifications. The random primer $\mathrm{pd}(\mathrm{N})_{6}$ (Random Hexamer, GE Healthcare, Little Chalfont, UK) was added to $8 \mu$ l of RNA, followed by incubation at $65^{\circ} \mathrm{C}$ for $10 \mathrm{~min}$. The reaction mixture was added, in a final volume of $20 \mu 1$ [1X enzyme buffer ( $50 \mathrm{mM}$ Tris- $\mathrm{HCl} \mathrm{pH} 8.3,75$ $\left.\mathrm{mM} \mathrm{KCl}, 3 \mathrm{mM} \mathrm{MgCl}{ }_{2}\right) / 10 \mathrm{mM} \mathrm{DTT} / 1 \mathrm{mM}$ of each dNTP (Invitrogen/Life Technologies)/20U Ribonuclease Inhibitor (Invitrogen/Life)/200U of RT, MMLV (Invitrogen/Life)] and the reaction proceeded at $37^{\circ} \mathrm{C}$ for $60 \mathrm{~min}$. The amplification reactions utilized primers designed for the VP1/ 2A junction region of the HAV genome. The first amplification reaction mixture was added to $5 \mu 1$ of the cDNA in a final volume of $25 \mu 1$ [1X enzyme buffer ( $20 \mathrm{mM}$ Tris- $\mathrm{HCl}$ $\mathrm{pH} 8.4,50 \mathrm{mM} \mathrm{KCl}) / 3 \mathrm{mM}$ of $\mathrm{MgCl}_{2} / 1.6 \mathrm{mM}$ of each dNTP (Invitrogen/Life)/0.8 mM of each primer F06 (CTATT CAGATTGCAAATTAYAAT) and F07 (AAYTTCAT YATTTCATGCTCCT)/1.5U Taq DNA polymerase (Invitrogen/Life)]. After denaturation at $94^{\circ} \mathrm{C}$ for $4 \mathrm{~min}$, the DNA was amplified for 30 cycles: $94^{\circ} \mathrm{C}-30 \mathrm{~s} ; 40^{\circ} \mathrm{C}$ $-30 \mathrm{~s} ; 72^{\circ} \mathrm{C}-1 \mathrm{~min}$, and $72^{\circ} \mathrm{C}$ for $7 \mathrm{~min}$. The nested PCR was carried out with $1 \mu \mathrm{l}$ of the first round PCR product, in a final volume of $25 \mu \mathrm{l}$ with the internal primers F8 (TATTTGTCTGTYACAGAACAATCAG) and F9 (AGGRGGTGGAAGYACTTCATTTGA). The reaction was conducted in 40 cycles, under the same conditions as in the first amplification, except for the annealing temperature $\left(48^{\circ} \mathrm{C}\right)$. The PCR products were loaded on a $2 \%$ agarose gel with ethidium bromide staining. Sterile Milli-Q water and HAV RNA positive serum sample, kindly provided by the Virology Department, Oswaldo Cruz Foundation, Rio de Janeiro, Brazil, were used as negative and positive controls, respectively.

Statistical analysis - The statistical analysis was performed using the Epi Info version 6 program, using the chi-squared $\left(\chi^{2}\right)$ test, and Fisher's exact test for proportion comparison, as well as $\chi^{2}$ for a trend test to evaluate possible tendencies. Differences were regarded as significant when $\mathrm{p}<0.05$.

\section{RESULTS}

Of 703 serum samples analyzed for the anti-HAV-IgM antibody, 46.4\% (326/703) were positive. Also, of 588 serum samples analyzed for HAV RNA, 13.1\% (77/588) showed positivity. In addition, of 22 fecal samples analyzed, 54.5\% (12/22) were positive for viral RNA. Of positive patients, 279 were positive only to the anti-HAV-IgM, 39 were positive to viral RNA only, and 47 were positive to both markers (Table I).

The viral RNA detection rate was 14 and $12.3 \%$ for anti-HAV-IgM positive and negative patients, respectively, considering serum samples and 66.6 and $40 \%$, respectively, based on fecal samples.

As far as age is concerned, greater HAV positivity was observed in individuals under ten years old, and this rate declined significantly as age increased (Table II).

A greater occurrence of HAV infection was noted during the summer $\left(60.6 \%-\chi^{2}=10.93, \mathrm{p}<0.05\right)$, data not shown. However, during the period of this study, there was a decline in virus occurrence from 1995 to 2002 ( $\chi^{2}$ for trend test $=16.664, \mathrm{p}<0.05)($ Fig. $)$.

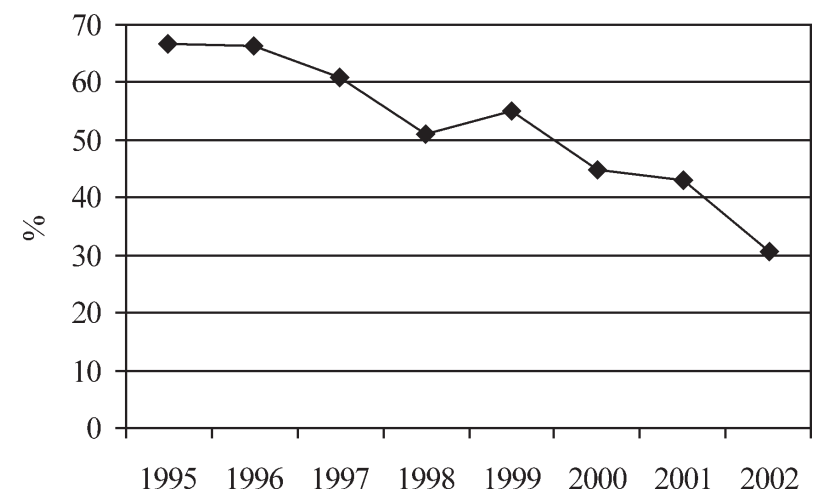

Hepatitis A virus positivity considering viral infection markers by collection year.

\section{DISCUSSION}

Hepatitis A occurs worldwide and is endemic to several regions. Prevalence of the disease varies widely, as a consequence of basic sanitation conditions. In this study, carried out over eight years with patients suspected of having hepatitis, the rate of HAV acute infection positivity (anti-HAV-IgM positive) was $46.4 \%$. This result is similar to those of other studies carried out in Brazil (Cardoso et al. 2000, de Paula et al. 2002, Villar et al. 2002a), even when considering the viral RNA positivity in the analyzed serum samples $(51.9 \%)$.

A similar viral RNA detection rate was observed taking into account samples with or without IgM antibody

TABLE I

Hepatitis A virus (HAV) positivity considering the viral infection markers in relation to the samples

\begin{tabular}{lccrr}
\hline & \multicolumn{3}{c}{ Samples } \\
\cline { 2 - 5 } Markers & Serum & Serum and feces & Feces & Total \\
\hline anti-HAV-IgM (+) & 279 & - & - & 279 \\
anti-HAV-IgM (+) and RNA (+) & 39 & 1 & 7 & 47 \\
anti-HAV-IgM (-) and RNA (+) & 35 & 2 & 2 & 39 \\
\hline Total & 353 & 3 & 9 & 365 \\
\hline
\end{tabular}


TABLE II

Hepatitis A virus positivity considering serological and molecular markers in relation to age, stratified by year

\begin{tabular}{|c|c|c|c|c|c|c|}
\hline Years & $\begin{array}{r}\text { Age } \\
\text { (years) }\end{array}$ & $\begin{array}{c}0-10 \\
\text { Positive/Total } \\
(\%)\end{array}$ & $\begin{array}{c}11-20 \\
\text { Positive/Total } \\
(\%)\end{array}$ & $\begin{array}{c}21-30 \\
\text { Positive/Total } \\
(\%)\end{array}$ & $\begin{array}{c}>31 \\
\text { Positive/Total } \\
(\%)\end{array}$ & $\begin{array}{c}\text { Total } \\
\text { Positive/Total } \\
(\%)\end{array}$ \\
\hline 1995 & & $\begin{array}{l}03 / 03 \\
(100)\end{array}$ & $\begin{array}{l}-1- \\
-\end{array}$ & $\begin{array}{l}01 / 03 \\
(33.3)\end{array}$ & $\begin{array}{l}-/- \\
-\end{array}$ & $\begin{array}{l}04 / 06 \\
(66.6)\end{array}$ \\
\hline 1996 & & $\begin{array}{l}26 / 31 \\
(83.9)\end{array}$ & $\begin{array}{c}10 / 11 \\
(90)\end{array}$ & $\begin{array}{l}04 / 09 \\
(44.4)\end{array}$ & $\begin{array}{l}02 / 11 \\
(18.2)\end{array}$ & $\begin{array}{l}42 / 62 \\
(67.7)\end{array}$ \\
\hline 1997 & & $\begin{array}{l}20 / 22 \\
(90.9)\end{array}$ & $\begin{array}{c}07 / 14 \\
(50)\end{array}$ & $\begin{array}{l}02 / 07 \\
(28.6)\end{array}$ & $\begin{array}{l}04 / 12 \\
(33.3)\end{array}$ & $\begin{array}{c}33 / 55 \\
(60)\end{array}$ \\
\hline 1998 & & $\begin{array}{l}16 / 21 \\
(76.2)\end{array}$ & $\begin{array}{c}03 / 05 \\
(60)\end{array}$ & $-/ 03$ & $-/ 06$ & $\begin{array}{l}19 / 35 \\
(54.3)\end{array}$ \\
\hline 1999 & & $\begin{array}{l}75 / 96 \\
(78.1)\end{array}$ & $\begin{array}{l}21 / 38 \\
(55.2)\end{array}$ & $\begin{array}{l}08 / 27 \\
(29.6)\end{array}$ & $\begin{array}{c}02 / 28 \\
(7.1)\end{array}$ & $\begin{array}{c}106 / 189 \\
(56.1)\end{array}$ \\
\hline 2000 & & $\begin{array}{l}51 / 76 \\
(67.1)\end{array}$ & $\begin{array}{l}30 / 46 \\
(65.2)\end{array}$ & $\begin{array}{l}11 / 37 \\
(29.7)\end{array}$ & $\begin{array}{r}02 / 43 \\
(4.6)\end{array}$ & $\begin{array}{c}94 / 202 \\
(46.5)\end{array}$ \\
\hline 2001 & & $\begin{array}{c}12 / 16 \\
(75)\end{array}$ & $\begin{array}{l}03 / 09 \\
(33.3)\end{array}$ & $\begin{array}{c}01 / 05 \\
(20)\end{array}$ & $-/ 07$ & $\begin{array}{c}16 / 37 \\
(41)\end{array}$ \\
\hline 2002 & & $\begin{array}{l}04 / 06 \\
(66.6)\end{array}$ & $\begin{array}{c}-/ 02 \\
-\end{array}$ & $\begin{array}{c}-/ 02 \\
-\end{array}$ & $\begin{array}{c}-/ 02 \\
-\end{array}$ & $\begin{array}{l}04 / 12 \\
(33.3)\end{array}$ \\
\hline Total $^{a}$ & & $\begin{array}{c}207 / 271 \\
(76.4)\end{array}$ & $\begin{array}{r}74 / 125 \\
(59.2)\end{array}$ & $\begin{array}{c}27 / 93 \\
(29)\end{array}$ & $\begin{array}{c}10 / 109 \\
(9.1)\end{array}$ & $\begin{array}{c}318 / 598^{b} \\
(53.2)\end{array}$ \\
\hline
\end{tabular}

$a: \chi^{2}$ for trend test $=165.239 ; \mathrm{p}<0.001 ; b$ : it was not possible obtain the age of 105 patients and of these, 47 were positive.

positivity. This result differs from those of other studies, which show greater molecular marker positivity from antiHAV-IgM positive samples (Fujiwara et al. 1997, Kwon et al. 2000, de Paula et al. 2002, 2004a, b, Villar et al. 2004, Poovorawan et al. 2005). This difference could be explained by the fact that the serum samples were stored for a long time and for this reason, the viral RNA could have been degraded. Also, the primers utilized were different from those used in some studies (Fujiwara et al. 1997, Kwon et al. 2000, Poovorawan et al. 2005). In any case, these results confirm the HAV circulation in Goiânia, underscore the importance of HAV RNA detection in the elucidation of acute hepatitis cases of unknown etiology, and suggest the need to adopt this methodology in blood banks.

HAV RNA was detected in $54.5 \%$ of the fecal samples, which is consistent with the results of other studies (Skinhoj et al. 1981, Yotsuyanagi et al. 1996, Villar et al. 2004). On the other hand, it was observed that this rate was significantly greater considering serum samples. It was suggested that this condition, also described in other studies, could be related to a greater viral concentration in the feces $\left(10^{8}\right.$ virions $\left./ \mathrm{g}\right)$ in relation to serum $\left(10^{5}\right.$ virions/ml) (Daemer et al. 1981, Rosenblum et al. 1991, Normann et al. 1995, Yotsuyanagi et al. 1996, Fujiwara et al. 1997).

Previous studies have shown that HAV infection in regions with a high endemicity pattern occur mainly in children under five years old (Ferreira et al. 1996, Vitral et al. 1998, Cardoso et al. 2000). Studies carried out in Latin America, including Brazil, as well as in other regions of the world have described a variation in the endemicity pattern of HAV infection, which has demonstrated a re- duction of this infection in children under five and a gradual increase among adolescents and adults (TapiaConyer et al. 1999, Barzaga 2000, Cianciara 2000, Tanaka 2000, Tufenkeji 2000, Villar et al. 2002b). The present study corroborates this endemicity pattern variation, demonstrating a decline in HAV infection from 1995 to 2002. On the other hand, in the present study, a greater percentage of HAV infection positivity was observed up to ten years of age $(76.4 \%)$, with a significant decline of the infection with the age increase, which characterizes a high endemicity pattern. Although the study population is not homogenous, these data were observed in every year of the study. This led to the suggestion that the Central region of Brazil is actually a high endemicity region. Thus, the data presented in this study underscore the extensive HAV circulation in our region, as well as suggesting the possibility of transmission of this virus by blood.

\section{ACKNOWLEDGEMENTS}

To Oswaldo Cruz Foundation for providing the positive serum samples.

\section{REFERENCES}

Barzaga NG 2000. Hepatitis A shifting epidemiology in SouthEast Asia and China. Vaccine 18: 61-64.

Boom R, Sol CJA, Salimans MMM, Jansen CL, Werthem-VenDillean PME, Noordaa JVD 1990. Rapid and simple method for purification of nucleic acids. J Clin Microbiol 28: 495503.

Büchen-Osmond C 2003. Taxonomy and classification of viruses. In Manual of Clinical Microbiology, 8th ed., ASM Press, Washington DC, p. 1217-1226. 
Buti M, Jardí R, Bosch A, Rodríguez F, Sánchez G, Pinto R, Costa X, Sánchez-Ávila JF, Cotrina M, Esteban R, Guardia J 2001. Valoración de la técnica de PCR-Southern blot para el análisis de la viremia en pacientes con hepatitis aguda A. Gastroenterol Hepatol 24: 1-4.

Cardoso DDP, Azevedo MSP, Martins RMB, Borges AMT, Queiroz DAO, Hidalgo AN, Fiaccadori FS, Daher RR 2000. Hepatite A em Goiânia, Goiás: epidemiologia descritiva da infecção de acordo com a faixa etária. Rev Pat Trop 29: 109112.

Carrilho FJ, Mendes CC, Silva LC 2005. Epidemiology of hepatitis A and E virus infection in Brazil. Gastroenterol Hepatol 28: $118-125$.

Cianciara J 2000. Hepatitis A shifting epidemiology in Poland and Eastern Europe. Vaccine 18: 68-70.

Costa-Mattioli M, Monpoeho S, Nicand E, Aleman MH, Billaudel S, Ferré V 2002. Quantification and duration of viraemia during hepatitis A infection as determined by realtime RT-PCR. J Viral Hepat 9: 101-106.

Daemer RJ, Feinstone SM, Gust ID, Purcell RH 1981. Propagation of human hepatitis A virus in African green monkey kidney cell culture: primary isolation and serial passage. Infect Immun 32: 388-393.

de Paula VS, Baptista ML, Lampe E, Niel C, Gaspar AMC 2002. Characterization of hepatitis A virus isolates from subgenotypes IA and IB in Rio de Janeiro, Brazil. J Med Virol 62: 22-27.

de Paula VS, Lu Ling, Niel Christian, Gaspar AMC, Robertson BH 2004a. Genetic analysis of hepatitis A virus isolates from Brazil. J Med Virol 73: 378-383.

de Paula VS, Villar LM, Morais LM, Lewis-Ximenez LL, Niel C, Gaspar AMC 2004b. Detection of hepatitis A virus RNA in serum during the window period of infection. J Clin Virol 29: 254-259.

Diwan AH, Stubbs JR, Carnahan GE 2003. Transmission of hepatitis A via WBC-reduced RBCs and FFP from a single donation. Transfusion 43: 536-540.

Ferreira CT, Silva GL, Barros FC, Lima JP 1996. Soroepidemiologia da hepatite A em dois grupos popu-lacionais economicamente distintos de Porto Alegre. GED 15: 85-90.

Fujiwara K, Yokosuka O, Ehata T, Imazeki F, Saisho H, Miki M, Omata M 1997. Frequent detection of hepatitis A viral RNA in serum during the early convalescent phase of acute hepatitis A. Hepatology 26: 1634-1639.

Gowland P, Fontana S, Niederhauser C, Taleghani BM 2004. Molecular and serologic tracing of a transfusion-transmitted hepatitis A virus. Transfusion 44: 1555-1561.

Koff RS 1998. Hepatitis A. Lancet 341: 1643-1649.

Kwon OS, Byun KS, Yeon JE, Park SH, Kim JS, Kim JH, Bak YT, Kim JH, Lee CH 2000. Detection of hepatitis A viral RNA in sera of patients with acute hepatitis A. Gastroenterol Hepatol 15: 1043-1047.
Lemon SM 1985. Type A viral hepatitis. New developments in an old disease. N Engl J Med 313: 1059-1067.

Normann A, Pfisterer-Hunt M, Schade S, Graff J, Chaves RL, Crovari P, Icardi G, Flehmig B 1995. Molecular epidemiology of an outbreak of hepatitis A in Italy. J Med Virol 47: 467-471.

Poovorawan Y, Theamboonlers A, Chongsrisawat V, Jantaradsamee P, Chutsirimongkol S, Tangkijvanich P 2005. Clinical features and molecular characterization of hepatitis A virus outbreak in a child care center in Thailand. J Clin Virol 32: 24-28.

Rosenblum LS, Villarino ME, Nainan OV, Melish ME, Hadler SC, Pinsky PP, Jarvis WR, Ott CE, Margolis HS 1991. Hepatitis A outbreak in a neonatal intensive care unit: risk factors for transmission and evidence of prolonged viral excretion among preterm infants. J Infect Dis 164: 476-482.

Seelig R, Renz M, Seelig HP 1992. PCR in the diagnosis of viral hepatitis. Ann Intern Med 24: 225-230.

Skinhoj P, Mathiesen LR, Kryger P, Moller Am 1981. Faecal excretion of hepatitis A virus in patients with symptomatic hepatitis A infection. Scand J Gastroenterol 16: 1057-1059.

Tanaka J 2000. Hepatitis A shifting epidemiology in Latin America. Vaccine 18: 57-60.

Tapia-Conyer R, Santos JI, Cavalcanti AM, Urdaneta E, Rivera L, Manterola A, Potin M, Ruttiman R, Kido JT 1999. Hepatitis A in Latin América: a changing epidemiologic pattern. Am J Trop Med Hyg 6: 825-829.

Tassopoulos NC, Papaevangelou GJ, Ticehurst JR, Purcell RH 1986. Fecal excretion of greek strains of hepatitis A virus in patients with hepatitis A and in experimentally infected chimpanzees. J Infect Dis 154: 231-237.

Tufenkeji H 2000. Hepatitis A shifting epidemiology in the Middle East and Africa. Vaccine 18: 65-67.

Villar LM, de Paula VS, Gaspar AMC 2002a. Seasonal variation of hepatitis A virus infection in the city of Rio de Janeiro, Brazil. Rev Inst Med Trop São Paulo 44: 289-292.

Villar LM, Costa MCE, de Paula VS, Gaspar AMC 2002b. Hepatitis A outbreak in a public school in Rio de Janeiro, Brazil. Mem Inst Oswaldo Cruz 97: 301-305.

Villar LM, Lampe E, Meyer A, Gaspar AMC 2004. Genetic variability of hepatitis A virus isolates in Rio de Janeiro: implications for the vaccination of school children. Braz J Med Biol Res 37: 1779-1787.

Vitral CL, Yoshida CFT, Lemos ERS, Teixeira CS, Gaspar AMC 1998. Age-specific prevalence of antibodies to hepatitis A in children and adolescents from Rio de Janeiro, Brazil, 1978 and 1995. Relationship of prevalence to environmental factors. Mem Inst Oswaldo Cruz 93: 1-5.

Yotsuyanagi H, Koike K, Yasuda K, Moriya K, Shintani Y, Fujie H, Kurokawa K, Iino S 1996. Prolonged fecal excretion of hepatitis A virus in adult patients with hepatitis A as determined by polymerase chain reaction. Hepatology 24: 10-13. 